\title{
Academic librarian salaries,
}

\section{7-1988}

\author{
By Mary Jo Lynch \\ Director \\ ALA Office for Research
}

\section{A summary of the CUPA survey of administrative compensation.}

T he College and University Personnel Association (CUPA) has conducted a survey of administrative compensation each year for the past eleven years. Selection of surveyed positions is based on an analysis of those positions common to most higher education institutions. Tables on librarian salaries drawn from CUPA's 1986-1987 Administrative Compensation Survey were published in the De-

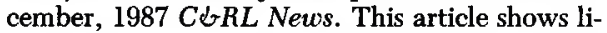
brarian salaries from the 1987-1988 edition. Permission of CUPA to use their data in this way is gratefully acknowledged. ${ }^{\prime}$

The 1987-1988 CUPA survey reports on 165 positions, including "Director, Library Services," "Circulation Librarian," "Acquisitions Librarian," "Technical Services Librarian" "Public Services Librarian," and "Reference Librarian." For all positions, salaries are summarized for control (i.e., public or private), three levels of program

${ }^{1}$ Richard C. Creal, Jan P. Miller, and John M. Toller, 1987-1988 Administrative Compensation Survey (Washington, D.C.: College and University Personnel Association, 1988). Available from CUPA at 1233 Twentieth Street, N.W., Suite 503, Washington, DC 20036. Price to members, \$55; price to non-members who participated in study, $\$ 145$; price to others, $\$ 250$. ISBN 0-910402-28-0. (i.e., university, 4-year college, 2 -year college), enrollment by quartile, and budget size by quartile. Tables in this article were created manually by selecting data on library director's salaries wherever they appear on the fifty-seven basic tables in the CUPA report. In addition, summary tables are shown for the five other librarian positions. Detailed tables, similar to those shown for Director, have been prepared for the five other positions and are available from CUPA for $\$ 5.00$ and a SASE (with $\$ .45$ postage). Send requests to: College and University Personnel Association, 1233 Twentieth St., N.W., Suite 503, Washington, DC 20036; (202) 429-0311. Prepayment must accompany requests for the tables. Tables for the five positions are available only as a set.

Two changes in the 1987-1988 CUPA report will be of interest to those seeking to compare data from year to year. The earlier report showed only Director salaries by enrollment and budget size ranges. In the 1987-1988 report such data are available for all six positions. The earlier report used ranges that broke at logical points (i.e. 5,000 to 9,$999 ; 10,000$ to 19,999$)$. In the 1987-1988 report both enrollment and budget size ranges show reporting institutions by quartile. Therefore, it will not always be possible to compare salaries in a range from year to year. Librarians will find it interesting to examine 
TABLE 1. Salaries paid to Director, Library Services: Overview

\begin{tabular}{lcccr}
\hline \hline & Med & $\mathbf{Q 1}$ & $\mathbf{Q 3}$ & $\mathbf{N}$ \\
All Institutions & $\$ 38,175$ & $\$ 29,660$ & $\$ 49,440$ & 1,236 \\
Medical Schools \& Centers & $\$ 54,700$ & $\$ 44,940$ & $\$ 59,500$ & 26 \\
2-Year Technical Institutes & $\$ 30,792$ & $\$ 26,000$ & $\$ 35,311$ & 18 \\
Theological Seminaries & $\$ 31,705$ & $\$ 26,575$ & $\$ 34,714$ & 29 \\
Private Independent Institutions & $\$ 35,107$ & $\$ 27,930$ & $\$ 46,500$ & 337 \\
Private Religious Institutions & $\$ 30,200$ & $\$ 24,819$ & $\$ 36,935$ & 292 \\
\hline
\end{tabular}

TABLE 2. Salaries paid to Director, Library Services: Universities

\begin{tabular}{|c|c|c|c|c|}
\hline All Universities & $\begin{array}{c}\text { Med } \\
\$ 52,044\end{array}$ & $\begin{array}{c}\text { Q1 } \\
\$ 41,936\end{array}$ & $\begin{array}{c}\text { Q3 } \\
\$ 63,936\end{array}$ & $\begin{array}{c}\mathbf{N} \\
385\end{array}$ \\
\hline $\begin{array}{c}\text { Public Universities by Enroll } \\
5,000 \text { or less } \\
5,001 \text { to } 10,000 \\
10,001 \text { to } 18,000 \\
18,001 \text { or more }\end{array}$ & $\begin{array}{l}\$ 40,980 \\
\$ 52,000 \\
\$ 60,900 \\
\$ 70,315\end{array}$ & $\begin{array}{l}\$ 36,625 \\
\$ 47,000 \\
\$ 55,825 \\
\$ 64,872\end{array}$ & $\begin{array}{l}\$ 46,545 \\
\$ 57,114 \\
\$ 66,925 \\
\$ 79,700\end{array}$ & $\begin{array}{l}60 \\
78 \\
61 \\
50\end{array}$ \\
\hline $\begin{array}{c}\text { Private Universities by Enrol } \\
2,000 \text { or less } \\
2,001 \text { to } 4,000 \\
4,001 \text { to } 7,000 \\
7,001 \text { or more }\end{array}$ & $\begin{array}{l}\$ 30,200 \\
\$ 39,500 \\
\$ 48,148 \\
\$ 70,000\end{array}$ & $\begin{array}{l}\$ 28,635 \\
\$ 34,071 \\
\$ 43,800 \\
\$ 58,200\end{array}$ & $\begin{array}{l}\$ 46,200 \\
\$ 46,500 \\
\$ 58,359 \\
\$ 88,000\end{array}$ & $\begin{array}{l}31 \\
44 \\
31 \\
30\end{array}$ \\
\hline $\begin{array}{c}\text { Public Universities by Budge } \\
\$ 29 \text { million or less } \\
\$ 29.1-\$ 61 \text { million } \\
\$ 61.1-\$ 169 \text { million } \\
\$ 169.1 \text { million or more }\end{array}$ & $\begin{array}{l}\$ 40,980 \\
\$ 49,548 \\
\$ 61,944 \\
\$ 71,300\end{array}$ & $\begin{array}{l}\$ 36,625 \\
\$ 44,949 \\
\$ 57,636 \\
\$ 65,664\end{array}$ & $\begin{array}{l}\$ 45,744 \\
\$ 53,500 \\
\$ 66,000 \\
\$ 79,700\end{array}$ & $\begin{array}{l}60 \\
66 \\
67 \\
56\end{array}$ \\
\hline $\begin{array}{l}\text { Private Universities by Budge } \\
\$ 21 \text { million or less } \\
\$ 21.1-\$ 34 \text { million } \\
\$ 34.1-\$ 83 \text { million } \\
\$ 83.1 \text { million or more }\end{array}$ & $\begin{array}{l}\$ 30,200 \\
\$ 39,675 \\
\$ 53,200 \\
\$ 74,160\end{array}$ & $\begin{array}{l}\$ 28,500 \\
\$ 36,000 \\
\$ 43,800 \\
\$ 63,100\end{array}$ & $\begin{array}{l}\$ 35,069 \\
\$ 45,795 \\
\$ 58,359 \\
\$ 90,000\end{array}$ & $\begin{array}{l}35 \\
34 \\
36 \\
31\end{array}$ \\
\hline
\end{tabular}

the report itself in order to compare their salaries with other administrators in the same type of institution.

The 1987-1988 questionnaire was sent to approximately 3,200 higher education institutions on a list provided by the National Center for Education Statistics (now the Center for Education Statistics). A total of 1,564 usable responses were received $-48 \%$ of the institutions surveyed. Salary data shown on tables in the CUPA report and in the tables which follow indicate the median, first quartile, and third quartile for each position.

The introduction to the CUPA report contains a useful description of those statistical concepts which is quoted below:
- The median is the middle value in an array of all salaries for the position; half of the salaries are lower than the median and half are higher. The median is considered a more reliable measure than the mean/average because it minimizes the effect of extremely high and low salaries.

- The first quartile (Q1 on Tables) divides salaries below the median into two 25 percent segments.

-The third quartile (Q3 on the Tables) divides salaries above the median into two 25 percent segments.

-Q1 and Q3, therefore, mark the interquartile range; half of all salaries-the middle 50 percentfall within this range. 
TABLE 3. Salaries paid to Director, Library Services: 4-Year Colleges

\begin{tabular}{|c|c|c|c|c|}
\hline All 4-Year Colleges & $\begin{array}{c}\text { Med } \\
\$ 32,370\end{array}$ & $\begin{array}{c}\text { Q1 } \\
\$ 26,563\end{array}$ & $\begin{array}{c}\text { Q3 } \\
\$ 41,446\end{array}$ & $\begin{array}{c}N \\
484\end{array}$ \\
\hline $\begin{array}{l}\text { Public 4-Year Colleges by Enrollment } \\
2,000 \text { or less } \\
2,001 \text { to } 3,000 \\
3,001 \text { to } 4,000 \\
4,001 \text { or more }\end{array}$ & $\begin{array}{l}\$ 34,000 \\
\$ 38,000 \\
\$ 42,070 \\
\$ 50,820\end{array}$ & $\begin{array}{l}\$ 30,847 \\
\$ 35,200 \\
\$ 37,862 \\
\$ 46,725\end{array}$ & $\begin{array}{l}\$ 37,600 \\
\$ 49,400 \\
\$ 46,068 \\
\$ 57,421\end{array}$ & $\begin{array}{l}28 \\
26 \\
16 \\
25\end{array}$ \\
\hline $\begin{array}{l}\text { Private 4-Year Colleges by Enrollment } \\
600 \text { or less } \\
601 \text { to } 1,000 \\
1,001 \text { to } 1,600 \\
1,601 \text { or more }\end{array}$ & $\begin{array}{l}\$ 23,590 \\
\$ 28,154 \\
\$ 33,423 \\
\$ 41,000\end{array}$ & $\begin{array}{l}\$ 20,700 \\
\$ 24,838 \\
\$ 29,000 \\
\$ 33,537\end{array}$ & $\begin{array}{l}\$ 27,000 \\
\$ 32,038 \\
\$ 39,800 \\
\$ 45,527\end{array}$ & $\begin{array}{r}85 \\
103 \\
101 \\
100\end{array}$ \\
\hline $\begin{array}{l}\text { Public 4-Year Colleges by Budget Range } \\
\$ 9 \text { million or less } \\
\$ 9.1-\$ 15 \text { million } \\
\$ 15.1-\$ 24 \text { million } \\
\$ 24.1 \text { million or more }\end{array}$ & $\begin{array}{l}\$ 32,220 \\
\$ 37,850 \\
\$ 46,068 \\
\$ 53,003\end{array}$ & $\begin{array}{l}\$ 29,447 \\
\$ 32,436 \\
\$ 43,200 \\
\$ 46,250\end{array}$ & $\begin{array}{l}\$ 36,151 \\
\$ 39,000 \\
\$ 50,085 \\
\$ 57,653\end{array}$ & $\begin{array}{l}21 \\
25 \\
26 \\
23\end{array}$ \\
\hline $\begin{array}{l}\text { Private } 4 \text {-Year Colleges by Budget Range } \\
\$ 6 \text { million or less } \\
\$ 6.1-\$ 9 \text { million } \\
\$ 9.1-\$ 18 \text { million } \\
\$ 15.1 \text { million or more }\end{array}$ & $\begin{array}{l}\$ 23,590 \\
\$ 28,906 \\
\$ 33,040 \\
\$ 42,500\end{array}$ & $\begin{array}{l}\$ 20,600 \\
\$ 26,000 \\
\$ 29,400 \\
\$ 36,450\end{array}$ & $\begin{array}{l}\$ 27,000 \\
\$ 32,251 \\
\$ 38,000 \\
\$ 48,690\end{array}$ & $\begin{array}{r}107 \\
80 \\
101 \\
101\end{array}$ \\
\hline
\end{tabular}

TABLE 4. Salaries paid to Director, Library Services: 2-Year Colleges

All 2-Year Colleges

Public 2-Year Colleges by Enrollment
1,300 or less
1,301-2,400
$2,401-4,700$
4,701 or more

Private 2-Year Colleges by Enrollment
300 or less
301 to 450
451 to 800

801 or more

Public 2-Year Colleges by Budget Range $\$ 5$ million or less

\$5.1-\$9 million

\$9.1-\$18 million

$\$ 18.1$ million or more

Private 2-Year Colleges by Budget Range

$\$ 2$ million or less

\$2.1-\$3 million

$\$ 3.1-\$ 5$ million

$\$ 5.1$ million or more
Med

$\$ 35,000$

$\$ 33,444$

$\$ 35,000$

$\$ 38,563$

$\$ 47,185$

$\$ 20,634$

$\$ 21,772$

$\$ 24,157$

$\$ 27,000$

$\$ 33,000$

$\$ 35,000$

$\$ 38,058$

$\$ 47,240$

$\$ 20,634$

$\$ 22,000$

$\$ 21,000$

$\$ 27,930$
Q1

$\$ 28,850$

$\$ 27,886$

$\$ 28,908$

$\$ 33,750$

$\$ 38,065$

$\$ 18,600$

$\$ 18,010$

$\$ 21,000$

$\$ 25,000$

$\$ 27,018$

$\$ 30,830$

$\$ 33,516$

$\$ 41,436$

$\$ 16,860$

$\$ 20,700$

$\$ 18,600$

$\$ 24,157$

Q3 N

$\$ 41,436$

253

$\$ 37,054$

$\$ 40,031$

$\$ 42,631$

$\$ 51,728$

$\$ 23,612$

$\$ 25,750$

$\$ 30,126$

$\$ 30,864$

$\$ 35,774$

$\$ 39,700$

$\$ 42,507$

$\$ 52,500$

62

66

44

46

9

8

11

$\$ 22,110$

$\$ 26,400$

$\$ 30,126$

$\$ 30,864$

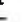


TABLE 5. Salaries paid to Circulation Librarian: Overview

All Institutions

Medical Schools \& Centers

Theological Seminaries

Private Independent Institutions

Private Religious Institutions

\section{Med}

$\$ 24,205$

$\$ 21,010$

$\$ 17,100$

$\$ 23,363$

$\$ 19,570$

\section{Q1}

$\$ 19,230$

$\$ 18,599$

$\$ 15,600$

$\$ 18,487$

$\$ 16,500$
Q3

$\$ 30,000$

$\$ 28,000$

$\$ 18,350$

$\$ 29,000$

$\$ 24,100$
N

505

8

13

124

112

\section{TABLE 6. Salaries paid to Acquisitions Librarian: Overview}

\section{All Institutions}

Medical Schools \& Centers

Theological Seminaries

Private Independent Institutions

Private Religious Institutions

Med
$\$ 27,400$
$\$ 26,373$
$\$ 21,504$
$\$ 25,840$
$\$ 21,200$

Q1

Q3

$\$ 33,400$

$\$ 31,657$

$\$ 22,330$

$\$ 31,120$

$\$ 25,733$
$\mathrm{N}$

522

9

5

135

96

TABLE 7. Salaries paid to Technical Services Librarian: Overview

$\begin{array}{lccrr} & \text { Med } & \text { Q1 } & \text { Q3 } & \text { N } \\ \text { All Institutions } & \$ 27,774 & \$ 22,062 & \$ 35,000 & 667 \\ \text { Medical Schools \& Centers } & \$ 27,510 & \$ 20,600 & \$ 34,493 & 16 \\ \text { Theological Seminaries } & \$ 23,620 & \$ 21,000 & \$ 25,680 & 12 \\ \text { Private Independent Institutions } & \$ 25,688 & \$ 21,037 & \$ 31,300 & 194 \\ \text { Private Religious Institutions } & \$ 22,184 & \$ 18,778 & \$ 26,873 & 136\end{array}$

TABLE 8. Salaries paid to Public Services Librarian: Overview

\begin{tabular}{|c|c|c|c|c|}
\hline & Med & Q1 & Q3 & $\mathrm{N}$ \\
\hline All Institutions & $\$ 30,000$ & $\$ 23,808$ & $\$ 38,019$ & 415 \\
\hline Medical Schools \& Centers & $\$ 30,116$ & $\$ 27,318$ & $\$ 37,404$ & 11 \\
\hline Theological Seminaries & $\$ 25,500$ & $\$ 24,000$ & $\$ 28,179$ & 5 \\
\hline Private Independent Institutions & $\$ 28,449$ & $\$ 22,300$ & $\$ 35,004$ & 111 \\
\hline Private Religious Institutions & $\$ 22,470$ & $\$ 18,000$ & $\$ 26,039$ & 68 \\
\hline
\end{tabular}

TABLE 9. Salaries paid to Reference Librarian: Overview

$\begin{array}{lcccr} & \text { Med } & \text { Q1 } & \text { Q3 } & \text { N } \\ \text { All Institutions } & \$ 25,883 & \$ 21,328 & \$ 32,017 & 708 \\ \text { Medical Schools \& Centers } & \$ 24,510 & \$ 21,896 & \$ 26,300 & 14 \\ \text { Theological Seminaries } & \$ 19,163 & \$ 16,000 & \$ 22,335 & 8 \\ \text { Private Independent Institutions } & \$ 24,266 & \$ 19,500 & \$ 29,910 & 192 \\ \text { Private Religious Institutions } & \$ 21,496 & \$ 18,200 & \$ 24,146 & 155\end{array}$


This means, for example, that if all library director salaries were arrayed from lowest to highest, the salary in the middle position, the median, would be $\$ 38,175$-the first figure shown in the top row on Table 1 . Another way of looking at the same array is to note that half of the salaries fall within a range bounded by $\$ 29,660$ - the first quartile (midway between the lowest salary and the median) and $\$ 49,440-$ the third quartile (midway between the median and the highest salary). The quartiles also show that 25 percent of academic library directors earn less than $\$ 29,660$ and 25 percent earn more than $\$ 49,440$.

It is also important to know that respondents were asked to observe the following specifications in reporting their data:

- Salaries are those in effect during the fall of 1987.

-Salaries are at an annualized, full-time rate; they reflect only actual cash earnings, excluding any services contributed without charge.

- Enrollment and budget figures are for the operating year 1987-1988.

- Enrollment is stated in terms of equivalent full-time students.

- Budgets include amounts for current education and general operations, including research funds. Budgets do not include amounts for student aid, auxiliary enterprises, service departments, construction, and similar activities.

\title{
Chapters Council:
}

\section{Reflections in a hall of mirrors}

\author{
By Alan Ritch \\ Assistant to the University Librarian \\ University of California, Santa Cruz
}

\section{The growth of ACRL chapters over the past 36 years.}

T wice a year, representatives of every chapter of the Association of College and Research Libraries gather as a Council to discuss issues of mutual concern. Only a few years ago these gatherings were sufficiently modest in scale that they could be held in small meeting rooms around a single table. At its most recent meeting in New Orleans, Chapters Council found itself in a large mirrored ballroom, forced by its own growing membership into a setting more august but less intimate than at conventions of the not too distant past.

Though the regional voices and the accents from all parts of the country were made less distinct by size and shape of the aptly named Versailles Room, the reflections that surrounded us, echoing multiple images of each delegation off into apparent distance seemed an appropriate metaphor for our function and our growing importance in the national organization. Just as the regional chapters provide to every ACRL member the opportunity for small-scale, grass-roots involvement, local continuing education, and social and professional interaction, so the Chapters Council serves as a parliament for all those local constituencies, as a forum for sharing program ideas, and as a setting which fosters new social and professional friendships. 